\title{
Volatile sulphur compounds composition of monovarietal white wines
}

\author{
Nathalie Moreira ${ }^{\mathrm{a}, *}$, Paula Guedes de Pinho ${ }^{\mathrm{b}}$, Cristina Santos ${ }^{\mathrm{a}}$, Isabel Vasconcelos ${ }^{\mathrm{a}}$

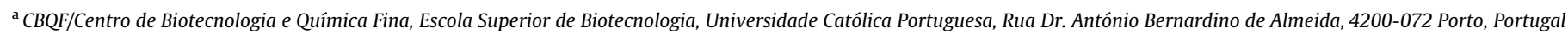 \\ ${ }^{\mathrm{b}}$ REQUIMTE/Departamento de Toxicologia, Faculdade de Farmácia, Universidade do Porto, R. Aníbal Cunha, 164, 4050-047 Porto, Portugal
}

Keywords:

GC/FPD

Heavy sulphur compounds

Cultivars

Alvarinho

Loureiro

Trajadura

Pedernã

Azal Branco

Avesso

Vinhos Verdes wines

\begin{abstract}
A B S T R A C T
The sulphur compounds composition of wines produced experimentally from six white cultivars (Alvarinho, Loureiro, Trajadura, Pedernã, Azal Branco and Avesso) was evaluated during two consecutive vintages. Results show that wines could be differentiated according to their sulphur compounds content. In general, Loureiro, Trajadura and Pedernã cultivars led to wines with low concentrations of sulphur compounds; however, Loureiro wines were characterised by significant amounts of dimethyl sulphone, whereas Trajadura wines possessed a high content of 3-(methylthio)propyl acetate and 4-(methylthio)-1-butanol. Alvarinho and Avesso wines showed high levels of $S$-methyl thioacetate, 3-mercapto1-propanol, 3-(ethylthio)-1-propanol and 3-methylthiopropionic acid. Significant amounts of 2-methyltetrahydrothiophen-3-one, cis- and trans-2-methyltetrahydrothiophen-3-ol were also found in Avesso wines. Azal Branco wines were low in 3-(methylthio)propyl acetate and 2-(methylthio)ethanol, and high contents in S-methyl thioacetate, 3-mercapto-1-propanol and 2-mercaptoethanol. A linear discriminant analysis of sulphur compounds levels showed a differentiation of wines according to their varietal origin.
\end{abstract}

\section{Introduction}

Thiols, disulphides and other sulphur-containing compounds play an important role in wine aroma. Sulphur compounds contribute mainly to unpleasant aromas in wines, although some of them have been reported to have a positive contribution to wine, mainly 4-mercapto-4-methyl-2-pentan-one, 3-mercaptohexyl acetate, 3-mercapto-1-hexan-ol, 4-mercapto-4-methyl-2-pentan-ol and 3-mercapto-3-methyl-l-butan-ol (Bouchilloux, Darriet, Henry, Lavigne-Cruège, \& Dubourdieu, 1998; Sarrazin et al., 2007; Tominaga \& Dubourdieu, 2006; Vermeulen, Gijs, \& Collin, 2005). Intensity and sensory impression of off-flavours depend on the qualitative and quantitative composition of volatile sulphur compounds in wines (Rauhut \& Kürbel, 1995). The light sulphur compounds (hydrogen sulphide, ethanethiol and methanethiol), possessing high volatility and low perception values, can be eliminated by simple racking or aeration, and by copper treatment (Anocibar Beloqui \& Bertrand, 1995; Darriet, Lavigne-Cruège, \& Tominaga, 1999; Karagiannis \& Lanaridis, 2000). The concentration of these compounds in reduced wines is higher than their perception thresholds and always higher than their concentrations in wines without off-flavours (Darriet et al., 1999; Mestres, Busto, \& Guasch, 2002). The heavy sulphur compounds cannot be eliminated and may have an unpleasant aroma even at low concentrations; moreover, they can become precursors of light sulphur compounds during wine storage (Anocibar Beloqui \& Bertrand, 1995; Mestres, Busto, \& Guasch, 2000). Threshold values and odour notes of heavy sulphur compounds are described in Table 1.

The volatile sulphur compounds in wines come mainly from the metabolism of yeast. The mechanisms of production of these compounds by yeasts are various and complex. The yeast strain, the grape variety, the ampelographic origin of wines, the vinification conditions, and the redox potential of must play a fundamental role on the levels of some sulphur compounds in wines (Falqué, Fernández, \& Dubourdieu, 2002; Spiropoulos, Tanaka, Flerianos, \& Bisson, 2000; Thomas, Boulton, Silacci, \& Gubler, 1993). A high turbidity of grape juice, a low nitrogen source and pantothenate deficiency of musts, a high temperature of fermentation and the excessive addition of sulphur dioxide to grape musts lead to an increase of sulphur compounds in wines; the conditions of conservation of wines in barriques or in stainless tanks, the duration of contact of wines with lees, and the storage time may also have important effects on the formation of these compounds in wines (Fedrizzi, Magno, Badocco, Nicolini, \& Versini, 2007; Karagiannis

* Corresponding author. Fax: +351225090351.

E-mail address: nemoreira@mail.esb.ucp.pt (N. Moreira). 
Table 1

Odour/flavour notes and threshold values of heavy sulphur compounds.

\begin{tabular}{|c|c|c|}
\hline Sulphur compound & Odour/flavour notes & Threshold values \\
\hline Methionol & $\begin{array}{l}\text { Cooked potato, cauliflower, cooked } \\
\text { vegetable/cabbage }\end{array}$ & $3200 \mu \mathrm{g} / \mathrm{l}$ in red wine, $4500 \mu \mathrm{g} / \mathrm{l}$ in white wine $\mathrm{w}^{\mathrm{b}, \mathrm{d}, \mathrm{g}} ; 500 \mu \mathrm{g} / \mathrm{l}$ in wine $\mathrm{w}^{\mathrm{f}, \mathrm{h}}$ \\
\hline S-Methyl thioacetate & Rotten/cooked vegetables, sulphurous ${ }^{\text {e,f }}$ & - \\
\hline 3-Mercapto-1-propanol & Sweat odour, roasted, potato, broth ${ }^{\mathrm{d}, \mathrm{i}}$ & $60 \mu \mathrm{g} / \mathrm{l}$ in model solution ${ }^{\mathrm{d}}$ \\
\hline 2-Mercaptoethanol & $\begin{array}{l}\text { Box tree, poultry, farmyard, alliaceous, } \\
\text { burnt rubber }{ }^{c, e, j, k}\end{array}$ & $\begin{array}{l}1-10 \mathrm{mg} / \mathrm{l} \text { in hydroalcoholic solution }{ }^{\mathrm{j}} ; 600 \mu \mathrm{g} / \mathrm{l} \text { in red wine, } 450 \mu \mathrm{g} / \mathrm{l} \text { in } \\
\text { white wine }^{\mathrm{d}} ; 0.13-10 \mathrm{mg} / \mathrm{l} \text { in wine } \mathrm{e}^{\mathrm{e}}\end{array}$ \\
\hline Dimethyl sulphone & Odourless $^{1}$ & - \\
\hline$N$-3-(Methylthiopropyl)acetamide & Odourless ${ }^{\mathrm{e}}$ & - \\
\hline 3-(Methylthio)propyl acetate & Mushroom, onion, garlic & $115 \mu \mathrm{g} / \mathrm{l}$ in red wine, $100 \mu \mathrm{g} / \mathrm{l}$ in white wine $\mathrm{b, \textrm {d } , \mathrm { g }}$ \\
\hline 4-(Methylthio)-1-butanol & $\begin{array}{l}\text { Metallic-bitter, grassy, onion, earthy, } \\
\text { chive-garlic }^{\text {b,d,e,j,k }}\end{array}$ & $80 \mu \mathrm{g} / \mathrm{l}$ in wine $\mathrm{w}^{\mathrm{k}} ; 0.1-1.0 \mathrm{mg} / \mathrm{l}$ in hydroalcoholic solution ${ }^{\mathrm{j}} ; 0.1 \mathrm{mg} / \mathrm{l}$ in wine $\mathrm{e}^{\mathrm{e}}$ \\
\hline 3-(Ethylthio)-1-propanol & Rancid, sweaty ${ }^{\mathrm{a}}$ & - \\
\hline 2-(Methylthio)ethanol & French bean, cauliflower ${ }^{c, d, e, k}$ & $250 \mu \mathrm{g} / \mathrm{l}$ in wine ${ }^{\mathrm{k}} ; 640 \mu \mathrm{g} / \mathrm{l}$ in red wine, $800 \mu \mathrm{g} / \mathrm{l}$ in white wine ${ }^{\mathrm{d}}$ \\
\hline 3-Methylthiopropionic acid & Chocolate, roasted, butter, rancid ${ }^{\mathrm{d}, \mathrm{e}, \mathrm{m}}$ & $50 \mu \mathrm{g} / 1$ in model solution ${ }^{\mathrm{d}} ; 244 \mu \mathrm{g} / 1$ in red wine ${ }^{\mathrm{m}}$ \\
\hline 2-Methyltetrahydrothiophen-3-one & Metallic, natural gas, butane-like $e^{\mathrm{c}, \mathrm{d}, \mathrm{e}, \mathrm{k}}$ & $250 \mu \mathrm{g} / \mathrm{l}$ in red wine, $150 \mu \mathrm{g} / \mathrm{l}$ in white wine ${ }^{\mathrm{d}}$ \\
\hline cis-2-Methyltetrahydrothiophen-3-ol & Odourless ${ }^{\mathrm{b}, \mathrm{d}, \mathrm{e}}$ & - \\
\hline trans-2-Methyltetrahydrothiophen-3-ol & Onion, chive-garlic ${ }^{\mathrm{b}, \mathrm{c}, \mathrm{d}, \mathrm{k}}$ & $100-500 \mu \mathrm{g} / \mathrm{l}$ in hydroalcoholic solution ${ }^{\mathrm{j}}$ \\
\hline
\end{tabular}

a Baumes et al. (1986).

b Chatonnet et al. (1992).

c Anocibar Beloqui and Bertrand (1995).

d Lavigne (1996)

e Mestres et al. (2000).

f Landaud, Helinck, and Bonnarme (2008).

g Lavigne et al. (1992).

h Swiegers, Bartowsky, Henschke, and Pretorius (2005).

i Vermeulen et al. (2005).

j Rapp, Güntert, and Almy (1985).

k Darriet et al. (1999).

${ }^{1}$ Ferreira, Rodrigues, Hogg, and Guedes de Pinho (2003).

m Pripis-Nicolau, Revel, Bertrand, and Lonvaud-Funel (2004).

\& Lanaridis, 1999, 2000; Lavigne \& Dubourdieu, 1996; Park, Boulton, \& Noble, 2000; Vasserot, Steinmetz, \& Jeandet, 2003; Wang, Bohlscheid, \& Edwards, 2003).

The Vinhos Verdes Denomination of Origin is located in the Northwest region of Portugal. The white wines possess an alcoholic content between $8.5 \%$ and $11.5 \%(\mathrm{v} / \mathrm{v})$, except the Alvarinho variety, whose alcoholic content must be between $11.5 \%$ and $13 \%$. These wines are slightly acidic and characterised by some effervescence. They are classified as soft wines with fruity notes of medium to high intensity. Very few reports are available in the literature concerning the volatile characterisation of white grape musts and wines from the Alvarinho, Loureiro, Trajadura, Pedernã, Azal Branco and Avesso cultivars; measurements of phenolic compounds, alcohols, organic acids and monoterpenic compounds composition of grapes and wines have been reported (Dopico-García, Valentão, Guerra, Andrade, \& Seabra, 2007; Oliveira et al., 2004; Oliveira, Faria, Sá, Barros, \& Araújo, 2006). The aim of this study is to evaluate the heavy sulphur compounds composition of Vinhos Verdes and investigate if cultivars can be differentiated according to that composition.

\section{Materials and methods}

\section{Grape musts and vinification conditions}

Experiments were carried out with white musts obtained from grapes of the Vitis vinifera varieties of the Vinhos Verdes Region: Alvarinho, Loureiro, Trajadura, Pedernã, Azal Branco and Avesso. Each variety was studied during two consecutive vintages.

The same technological procedure was applied in the production of all wines. Grapes were picked at random, from the same location. Harvested grapes were crushed, pressed and treated with sulphite solution to achieve $30 \mathrm{mg} / \mathrm{l}$. After settling overnight at $5{ }^{\circ} \mathrm{C}$, grape musts were racked into $10-\mathrm{l}$ glass tanks. All experiments were carried out in duplicate. Fermentations were initiated by starter cultures of rehydrated Saccharomyces cerevisiae at 20 g/hl (commercial name Fermol Bouquet, from Pascal Biotech, controlled by the General Microbiology Laboratory of the Faculty of Science of the University of Reims-Champagne, France). Fermentations were carried out at $18^{\circ} \mathrm{C}$ and considered complete when no variation of sugar content was observed (below $5 \mathrm{~g} / \mathrm{l}$ ), and before occurrence of malolactic fermentation. Wines were cold-stabilized and then the sulphite content was adjusted to $30 \mathrm{mg} / \mathrm{l}$ free. After bottling, wines were stored at $15^{\circ} \mathrm{C}$.

\section{Analytical determinations}

For each wine, the total and volatile acidity, $\mathrm{pH}$, alcoholic degree, free and total $\mathrm{SO}_{2}$ were determined using standard procedures, as described by the Office International de la Vigne et du Vin (OIV, 1990).

Sulphur compounds were determined by gas chromatography with flame photometric detection (GC/FPD), according to the method described by Moreira, Guedes de Pinho, and Vasconcelos (2004). The sulphur compounds analysed were (CAS number in brackets): S-methyl thioacetate [1534-08-3], 2-mercaptoethanol [60-24-2], 2-(methylthio)ethanol [5271-38-5], 2-methyltetrahydrothiophen-3-one [13679-85-1], 3-(methylthio)propyl acetate [16630-55-0], 3-methylthiopropionic acid [646-01-05], 3-mercapto-1-propanol [19721-22-3], 3-(methylthio)-1-propanol (methionol) [505-10-2], cis- and trans-2-methyltetrahydrothiophen-3-ol ([62614-75-9] and [62614-77-1], respectively), 3-(ethylthio)-1-propanol [18721-61-4], 4-(methylthio)-1-butanol [20582-85-8], dimethyl sulphone [67-71-0] and $\mathrm{N}$-[3-(methylthio)propyl]acetamide [54824-91-8]. For those compounds whose reference standards were commercially available, a calibration per mass was carried out and concentrations were expressed as $\mu \mathrm{g} / \mathrm{l}$. Amounts of compounds whose reference standards were not commercially available were expressed as:

peak area $\times 1000 /$ peak area of internal standard. 


\section{Statistical analysis}

An analysis of variance (ANOVA) was applied to the experimental data; results were considered significant if the associated $p$ value was below 0.05 . The significant differences were determined by Tukey tests. A principal component analysis and a linear discriminant analysis were also applied to data. All statistical analysis were performed using SPSS for Windows, Version 10.0 (SPSS Inc., Chicago, IL).

\section{Results and discussion}

\section{Wine parameters}

Significant differences of $\mathrm{pH}$, total acidity, alcoholic degree and total $\mathrm{SO}_{2}$ were obtained in wines resulting from different grape cultivars (Table 2). The $\mathrm{pH}$ values varied between 2.19 and 3.13, and presented the highest values in Year 2, except for Loureiro and Trajadura wines. The highest amounts of total acidity were found in Azal Branco wines in both vintages (11.7 and $10.9 \mathrm{~g} / \mathrm{l}$ ), as well as in Loureiro wines in the 2 nd year $(11.0 \mathrm{~g} / \mathrm{l})$. The Alvarinho and Trajadura wines presented the lowest total acidity values $(7.3-8.1 \mathrm{~g} / \mathrm{l})$ in both vintages. The values of volatile acidity were similar in all wines, varying between 0.34 and $0.65 \mathrm{~g} / \mathrm{l}$. The highest alcoholic degree values were obtained, as expected, in Alvarinho wines (11.6\% and $12.4 \%$ ); this parameter varied between $8.88 \%$ and $10.9 \%$ for the other wines. These values are in agreement with Portuguese legislation for the Appellation of Origin Vinhos Verdes that recommends/imposes an alcoholic degree between $8.0 \%$ and $11.5 \%$, except for Alvarinho wines, whose values must be between $11.5 \%$ and $13.0 \%$, and a total acidity of at least $6.0 \mathrm{~g} / \mathrm{l}(4.5 \mathrm{~g} / \mathrm{l}$ for Alvarinho wine). Previously published data for the same grape cultivars presented similar values of $\mathrm{pH}$, varying between 2.70 and 3.08 , total acidity, within 6.57 and $11.4 \mathrm{~g} / \mathrm{l}$, volatile acidity, within 0.24 and $0.81 \mathrm{~g} / \mathrm{l}$, and alcoholic degree, varying between $8.9 \%$ and 12.8\%; Alvarinho showed higher alcoholic degree values, 13.513.9\% (Oliveira et al., 2006).

The free $\mathrm{SO}_{2}$ concentration presented similar values in wines of Year 2; however, for Year 1, some differences were observed, with Trajadura, Pedernã and Azal Branco wines presenting the lowest contents of free $\mathrm{SO}_{2}$. The total $\mathrm{SO}_{2}$ concentration in wines also varied, and the highest values in both vintages were observed in Trajadura wines.

\section{Principal component analysis of data}

Sulphur compounds content of wines are presented in Tables 3 and 4 . In general, when significant, the amounts of sulphur compounds in wines were higher in Year 2 than in Year 1.

A principal component analysis (PCA) was applied to all samples to obtain a simplified view of the relationship between the wines. Three factors explain $72.8 \%$ of the total variance. The

Table 2

Oenological parameters of Trajadura, Pedernã, Loureiro, Alvarinho, Azal Branco and Avesso wines.

\begin{tabular}{|c|c|c|c|c|c|c|c|}
\hline Vintage & Parameters & Trajadura & Pedernã & Loureiro & Alvarinho & Azal Branco & Avesso \\
\hline \multirow[t]{6}{*}{ Year 1} & $\mathrm{pH}$ & $2.96(0.02)^{\mathrm{b}}$ & $2.72(0.07)^{a}$ & $2.64(0.03)^{a}$ & $2.70(0.02)^{a}$ & $2.63(0.05)^{\mathrm{a}}$ & $2.67(0.02)^{\mathrm{a}}$ \\
\hline & Total acidity $(\mathrm{g} / \mathrm{l})^{\mathrm{A}}$ & $7.4(0.2)^{\mathrm{a}}$ & $9.8(0.5)^{\mathrm{c}}$ & $8.8(0.3)^{\mathrm{b}}$ & $8.0(0.3)^{\mathrm{a}}$ & $11.7(0.30)^{\mathrm{d}}$ & $10.1(0.2)^{\mathrm{c}}$ \\
\hline & Volatile acidity $(\mathrm{g} / \mathrm{l})^{\mathrm{B}}$ & $0.46(0.03)$ & $0.65(0.18)$ & $0.34(0.04)$ & $0.44(0.07)$ & $0.61(0.16)$ & $0.45(0.05)$ \\
\hline & Alcoholic degree $(\mathrm{v} / \mathrm{v})$ & $9.13(0.22)^{a}$ & $9.62(0.99)^{\mathrm{a}}$ & $9.64(0.21)^{a}$ & $12.4(0.5)^{c}$ & $8.88(0.42)^{a}$ & $10.9(0.1)^{b}$ \\
\hline & Free $\mathrm{SO}_{2}(\mathrm{mg} / \mathrm{l})$ & $11.8(2.1)^{\mathrm{a}}$ & $11.3(1.5)^{\mathrm{a}}$ & $20.5(5.0)^{\mathrm{b}}$ & $21.3(2.22)^{\mathrm{b}}$ & $15.0(2.1)^{\mathrm{ab}}$ & $21.3(4.9)^{\mathrm{b}}$ \\
\hline & Total $\mathrm{SO}_{2}(\mathrm{mg} / \mathrm{l})$ & $124(3.4)^{\mathrm{b}}$ & $92.0(15.4)^{\mathrm{a}}$ & $92.3(14.8)^{\mathrm{a}}$ & $80.5(4.8)^{\mathrm{a}}$ & $79.8(2.7)^{\mathrm{a}}$ & $73.8(1.7)^{\mathrm{a}}$ \\
\hline \multirow[t]{6}{*}{ Year 2} & $\mathrm{pH}$ & $2.89(0.13)^{\mathrm{b}}$ & $2.98(0.10)^{\mathrm{bc}}$ & $2.19(0.19)^{\mathrm{a}}$ & $3.13(0.04)^{\mathrm{c}}$ & $2.88(0.06)^{\mathrm{b}}$ & $3.02(0.13)^{\mathrm{bc}}$ \\
\hline & Total acidity $(\mathrm{g} / \mathrm{l})^{\mathrm{A}}$ & $7.3(0.5)^{\mathrm{a}}$ & $9.2(0.7)^{\mathrm{c}}$ & $11.0(0.6)^{\mathrm{d}}$ & $8.1(0.3)^{\mathrm{b}}$ & $10.9(0.7)^{\mathrm{d}}$ & $9.4(0.5)^{\mathrm{c}}$ \\
\hline & Volatile acidity $(\mathrm{g} / \mathrm{l})^{\mathrm{B}}$ & $0.39(0.09)$ & $0.42(0.06)$ & $0.42(0.11)$ & $0.52(0.16)$ & $0.40(0.05)$ & $0.49(0.06)$ \\
\hline & Alcoholic degree $(\mathrm{v} / \mathrm{v})$ & $9.56(0.44)^{b}$ & $10.8(0.2)^{\mathrm{c}}$ & $8.89(0.52)^{a}$ & $11.6(0.3)^{\mathrm{d}}$ & $9.92(0.33)^{b}$ & $10.9(0.4)^{\mathrm{c}}$ \\
\hline & Free $\mathrm{SO}_{2}(\mathrm{mg} / \mathrm{l})$ & $23.9(5.4)$ & $29.8(6.6)$ & $27.5(11.7)$ & $24.9(7.7)$ & $23.9(8.1)$ & $29.0(7.3)$ \\
\hline & Total $\mathrm{SO}_{2}(\mathrm{mg} / \mathrm{l})$ & $105(15)^{\mathrm{bc}}$ & $89.1(11.2)^{b}$ & $101(19)^{\mathrm{bc}}$ & $118(25)^{\mathrm{c}}$ & $64.3(14.1)^{\mathrm{a}}$ & $92.9(18.9)^{\mathrm{b}}$ \\
\hline
\end{tabular}

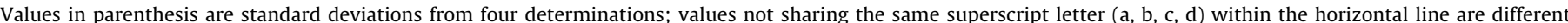
according to the Tukey test.

A Expressed as tartaric acid.

${ }^{B}$ Expressed as acetic acid.

Table 3

Heavy sulphur compounds contents $(\mu \mathrm{g} / \mathrm{l})$ of Loureiro, Trajadura and Pedernã wines in two vintages.

\begin{tabular}{|c|c|c|c|c|c|c|c|c|c|}
\hline \multirow[t]{2}{*}{ Compound } & \multicolumn{3}{|l|}{ Loureiro } & \multicolumn{3}{|l|}{ Trajadura } & \multicolumn{3}{|l|}{ Pedernã } \\
\hline & Year 1 & Year 2 & Sig. & Year 1 & Year 2 & Sig. & Year 1 & Year 2 & Sig. \\
\hline Methionol & $412(125)$ & $611(155)$ & ns & $374(1)$ & $758(292)$ & ns & $390(1)$ & $1122(168)$ & 0.025 \\
\hline S-Methyl thioacetate & $3.71(0.01)$ & $10.2(2.0)$ & 0.044 & $2.24(0.34)$ & $8.43(0.35)$ & 0.003 & $1.92(0.12)$ & $6.27(1.46)$ & ns \\
\hline 3-Mercapto-1-propanol & $20.0(4.2)$ & $19.5(2.4)$ & ns & $12.1(0.1)$ & $21.8(3.9)$ & ns & $9.87(0.18)$ & $28.4(5.3)$ & 0.038 \\
\hline 2-Mercaptoethanol & $30.2(7.9)$ & $25.2(1.7)$ & ns & $13.1(0.2)$ & $46.2(1.8)$ & 0.001 & $15.1(0.1)$ & $52.0(7.7)$ & 0.021 \\
\hline Dimethyl sulphone & $42.2(0.7)$ & $38.3(0.9)$ & 0.042 & $13.8(1.2)$ & $18.2(4.0)$ & ns & $12.2(0.3)$ & $24.0(1.9)$ & 0.013 \\
\hline 3-(Methylthio)propyl acetate ${ }^{a}$ & $1.40(0.28)$ & $8.60(0.01)$ & 0.001 & $5.10(0.14)$ & $25.8(4.5)$ & 0.023 & $2.75(0.35)$ & $28.9(3.8)$ & 0.011 \\
\hline 4-(Methylthio)-1-butanol & $14.6(1.0)$ & $20.6(3.9)$ & ns & $25.4(0.6)$ & $28.7(6.0)$ & ns & $11.6(2.2)$ & $26.1(0.8)$ & 0.013 \\
\hline N-3-(Methylthiopropyl)acetamide ${ }^{\mathrm{a}}$ & $390(73)$ & $278(66)$ & ns & $30.6(0.6)$ & $1119(77)$ & 0.002 & $22.1(0.1)$ & $656(56)$ & 0.004 \\
\hline 3-(Ethylthio)-1-propanol & $21.4(1.1)$ & $16.5(1.1)$ & 0.048 & $19.0(0.1)$ & $21.8(2.4)$ & ns & $9.33(0.46)$ & $18.2(1.6)$ & 0.017 \\
\hline 3-Methylthiopropionic acid ${ }^{a}$ & $82.1(11.0)$ & $75.1(6.2)$ & ns & $16.2(0.2)$ & $170(13)$ & 0.004 & $16.1(0.1)$ & $230(4)$ & 0.000 \\
\hline 2-Methyltetrahydrothiophen-3-one & $64.4(12.5)$ & $111(2)$ & 0.034 & $70.3(0.4)$ & $221(76)$ & ns & $85.0(1.4)$ & $134(19)$ & ns \\
\hline cis-2-Methyltetrahydrothiophen-3-ol ${ }^{\mathrm{a}}$ & $20.4(1.9)$ & $92.4(18.8)$ & 0.033 & $61.5(0.7)$ & $194(56)$ & ns & $62.7(0.4)$ & $106(1)$ & 0.000 \\
\hline trans-2-Methyltetrahydrothiophen-3-ol ${ }^{\mathrm{a}}$ & $12.4(0.6)$ & $123(2)$ & 0.000 & $71.1(1.3)$ & $231(50)$ & ns & $54.2(0.2)$ & $129(3)$ & 0.001 \\
\hline 2-(Methylthio)ethanol & $7.51(0.27)$ & $8.61(0.94)$ & ns & $11.8(0.3)$ & $11.5(0.6)$ & ns & $10.8(0.3)$ & $18.3(1.0)$ & 0.010 \\
\hline
\end{tabular}

Values in parenthesis are standard deviations from four determinations. Sig.: significance; ns: not significant $(p>0.05)$.

a Peak area $\times 10^{3}$ per peak area of internal standard. 
Table 4

Heavy sulphur compounds contents $(\mu \mathrm{g} / \mathrm{l})$ of Alvarinho, Azal Branco and Avesso wines in two vintages.

\begin{tabular}{|c|c|c|c|c|c|c|c|c|c|}
\hline \multirow[t]{2}{*}{ Compound } & \multicolumn{3}{|l|}{ Alvarinho } & \multicolumn{3}{|l|}{ Azal Branco } & \multicolumn{3}{|l|}{ Avesso } \\
\hline & Year 1 & Year 2 & Sig. & Year 1 & Year 2 & Sig. & Year 1 & Year 2 & Sig. \\
\hline Methionol & $465(28)$ & $690(50)$ & 0.032 & $384(49)$ & $857(7)$ & 0.006 & $472(3)$ & $898(126)$ & 0.041 \\
\hline S-Methyl thioacetate & $8.46(0.45)$ & $11.5(7.6)$ & ns & $8.34(2.14)$ & $13.4(0.5)$ & ns & $8.52(0.18)$ & $13.6(0.7)$ & 0.011 \\
\hline 3-Mercapto-1-propanol & $19.9(1.3)$ & $62.0(13.2)$ & 0.047 & $26.6(2.5)$ & $44.9(3.2)$ & 0.024 & $38.5(9.2)$ & $37.9(0.6)$ & ns \\
\hline 2-Mercaptoethanol & $30.1(13.7)$ & $37.6(21.6)$ & ns & $57.9(10.2)$ & $19.0(0.6)$ & 0.033 & $71.5(1.6)$ & $57.2(6.6)$ & ns \\
\hline Dimethyl sulphone & $23.8(3.8)$ & $15.1(0.3)$ & ns & $14.3(0.4)$ & $30.3(1.4)$ & 0.004 & $16.7(1.7)$ & $28.7(1.5)$ & 0.017 \\
\hline 3-(Methylthio)propyl acetate ${ }^{a}$ & $1.60(0.57)$ & $6.92(1.24)$ & 0.032 & $1.09(0.08)$ & $9.25(1.5)$ & 0.017 & $2.75(0.49)$ & $19.0(1.1)$ & 0.003 \\
\hline 4-(Methylthio)-1-butanol & $10.9(1.5)$ & $19.1(0.7)$ & 0.019 & $21.0(1.4)$ & $15.9(3.1)$ & ns & $9.85(0.81)$ & $11.1(2.3)$ & ns \\
\hline$N$-3-(Methylthiopropyl)acetamide a & $32.9(3.7)$ & $20.0(1.1)$ & 0.040 & $72.5(19.1)$ & $29.1(2.2)$ & ns & $40.8(1.9)$ & $193(35)$ & 0.025 \\
\hline 3-(Ethylthio)-1-propanol & $23.0(8.5)$ & $61.0(13.2)$ & ns & $21.8(4.4)$ & $22.8(3.1)$ & ns & $30.8(1.3)$ & $16.3(0.9)$ & 0.006 \\
\hline 3-Methylthiopropionic acid ${ }^{a}$ & $176(53)$ & $683(318)$ & ns & $24.3(2.3)$ & $301(22)$ & 0.003 & $256(54)$ & $199(1)$ & ns \\
\hline 2-Methyltetrahydrothiophen-3-one & $42.6(7.4)$ & $138(29)$ & 0.046 & $97.8(0.5)$ & $136(10)$ & 0.034 & $245(84)$ & $155(13)$ & ns \\
\hline cis-2-Methyltetrahydrothiophen-3-ol a & $58.0(7.1)$ & $224(9)$ & 0.002 & $31.4(6.3)$ & $80.0(16.0)$ & ns & $243(124)$ & $144(21)$ & ns \\
\hline trans-2-Methyltetrahydrothiophen-3-ol a & $19.2(2.1)$ & $139(5)$ & 0.001 & $21.6(2.1)$ & $82.5(10.4)$ & 0.015 & $303(136)$ & $243(28)$ & ns \\
\hline 2-(Methylthio)ethanol & $10.6(1.7)$ & $15.0(0.9)$ & ns & $6.70(0.14)$ & $8.72(0.60)$ & 0.043 & $6.20(0.14)$ & $13.3(0.8)$ & 0.007 \\
\hline
\end{tabular}

Values in parenthesis are standard deviations from four determinations. Sig.: significance; ns: not significant $(p>0.05)$.

a Peak area $\times 10^{3}$ per peak area of internal standard.

representation of the variables and samples using the first two PCs is shown in Fig. 1A and B. The variables 4-(methylthio)-1-butanol, dimethyl sulphone, volatile acidity, free and total $\mathrm{SO}_{2}$ were not used in the analysis, as they presented a communality value lower than 0.5 . The variables with higher contribution to the first principal component (PC1), which explains $39.4 \%$ of total variance, are the alcoholic degree (alc), 3-mercapto-1-propanol (S6), 2-methyltetrahydrothiophen-3-one (S4), 3-methylthiopropionic acid (S9), cis- (S11) and trans-2-methyltetrahydrothiophen-3-ol (S12). All these variables are positively correlated to PC1. The second principal component (PC2), which explains $17.6 \%$ of total variance, is positively related to total acidity (AcT), and negatively related to 2-(methylthio)ethanol (S3), 3-(methylthio)propyl acetate (S5) and $\mathrm{N}$-3-(methylthiopropyl)acetamide (S10). Results show that wines tend to separate according to the vintage, except for Loureiro wines. Trajadura, Pedernã, Alvarinho and Azal Branco wines from the 1 st vintage and all Loureiro wines are placed in the negative PC1, being characterised by lower contents of the associated variables, whereas wines from the 2nd vintage, and all Avesso wines, are mainly related to the positive PC1. Trajadura and Pedernã wines of the same vintage, placed closer in the projection, are similar concerning the variables used, and are related to the negative PC2. The differences observed according to the vintage may be associated to different climatic conditions, which affect the nutrients level of grape musts (Park et al., 2000; Wang et al., 2003).

\section{Heavy sulphur compounds composition of wines}

Methionol is the heavy sulphur compound present in wines in the highest concentrations (Tables 3 and 4). No significant differences were obtained in methionol contents of wines from the same vintage. In Year 1, wines presented concentrations of methionol varying from 374 to $472 \mu \mathrm{g} / \mathrm{l}$, whereas higher values of this compound (611-1122 $\mu \mathrm{g} / \mathrm{l})$ were obtained in Year 2 . These methionol concentrations were below its threshold value in white wines (Table 1). According to Falqué et al. (2002), methionol concentration was one of the variables responsible for the differentiation of wines from Loureiro, Dona Branca and Trajadura cultivars from the Galicia region (Spain). Methionol is produced by yeast from methionine, via deamination, followed by decarboxylation (Ehrlich reaction); the aldehyde thus formed, 3-(methylthio)-1-propanal (methional), is then reduced to the alcohol (methionol) or oxidised to the acid (3-(methylthio)propionic acid). The reaction of methionol with acetic acid yields 3-(methylthio)propyl acetate (Rauhut, 1993). Baumes, Cordonnier, Nitz, and Drawert (1986) reported
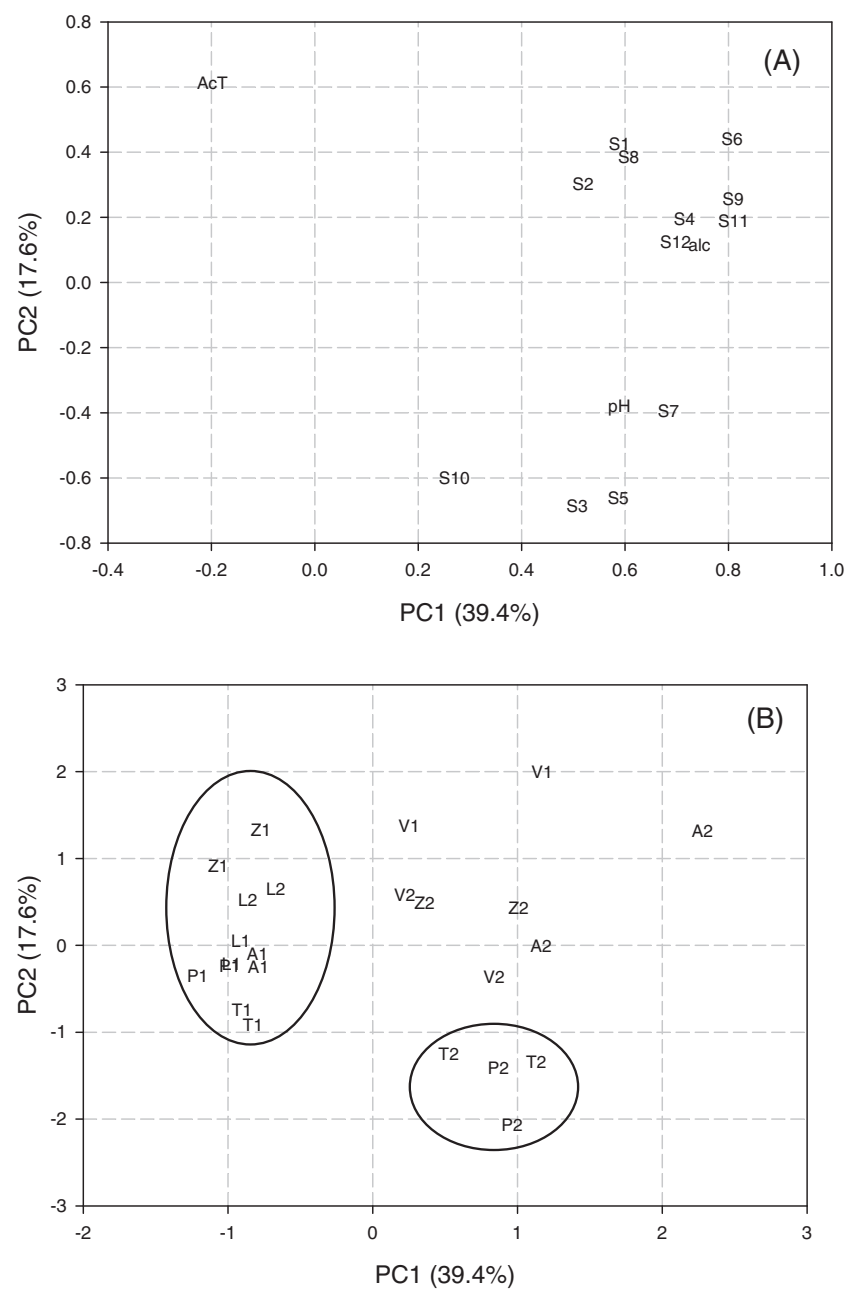

Fig. 1. Principal component analysis: projection of variables and wines on the space defined by the first and second principal components. (A) Variables: S-methyl thioacetate (S1), 2-mercaptoethanol (S2), 2-(methylthio)ethanol (S3), 2-methyltetrahydrothiophen-3-one (S4), 3-(methylthio)propyl acetate (S5), 3-mercapto-1propanol (S6), methionol (S7), 3-(ethylthio)-1-propanol (S8), 3-methylthiopropionic acid (S9), N-3-(methylthiopropyl)acetamide (S10), cis- (S11) and trans-2methyltetrahydrothiophen-3-ol (S12), pH, total acidity (AcT) and alcoholic degree (alc). (B) Wines: Trajadura (T), Pedernã (P), Alvarinho (A), Loureiro (L), Azal Branco $(\mathrm{Z})$ and Avesso $(\mathrm{V})$, followed by 1 (1st vintage) or 2 (2nd vintage). 
concentrations of methionol from 507 to $998 \mu \mathrm{g} / \mathrm{l}$ in white wines; however, higher values, up to $5000 \mu \mathrm{g} / \mathrm{l}$, have also been reported in wines (Anocibar Beloqui \& Bertrand, 1995; Chatonnet, Dubourdieu, \& Boidron, 1992; Fedrizzi, Magno, Badocco, et al., 2007; Fedrizzi, Magno, Moser, Nicolini, \& Versini, 2007; Ugliano et al., 2009). The content of methionol increased considerately in wines with reduction defects (Chatonnet et al., 1992; Mestres et al., 2000, 2002), contributing odours of potato, cauliflower and cooked vegetables/cabbage (Table 1 ).

In general, Loureiro, Trajadura and Pedernã cultivars led to wines with low concentrations of sulphur compounds, being characterised by low contents in $S$-methyl thioacetate, 3-mercapto-1-propanol and 2-mercaptoethanol. S-methyl thioacetate concentrations of wines varied between 1.92 and $13.6 \mu \mathrm{g} / \mathrm{l}$. The highest levels of this compound were obtained in Alvarinho, Avesso and Azal Branco wines. Values of $S$-methyl thioacetate, from 0 to $70 \mu \mathrm{g} / \mathrm{l}$, have been reported in wines, and concentrations in wines can reach up to $115 \mu \mathrm{g} / \mathrm{l}$ (Fedrizzi, Magno, Badocco, et al., 2007; Mestres et al., 2000). This compound possesses an objectionable odour of rotten/cooked vegetables and sulphurous. In general, the highest contents in 3mercapto-1-propanol were also obtained for Alvarinho, Azal Branco and Avesso wines (19.9-62.0 $\mu \mathrm{g} / \mathrm{l}$ ). Loureiro, Trajadura and Pedernã wines showed concentrations of this compound of 9.87-28.4 $\mu \mathrm{g} / \mathrm{l}$. Concentrations lower than $13.5 \mu \mathrm{g} / \mathrm{l}$ were reported in white wines (Lavigne, 1996). 3-Mercapto-1-propanol may have a negative influence on wine aroma at contents higher than its threshold value (Table 1). 2-Mercaptoethanol concentrations varied between 13.1 and $71.5 \mu \mathrm{g} / \mathrm{l}$; in general, the highest amounts were observed in Azal Branco and Avesso wines. Values varying between 2 and $55 \mu \mathrm{g} / \mathrm{l}$ were reported in white and red wines (Anocibar Beloqui, 1998; Fedrizzi, Magno, Badocco, et al., 2007; Ugliano et al., 2009). Its negative influence on wine quality seems unlikely, because the estimated concentrations found in wines are far below its threshold value.

Loureiro wines were also characterised by significant amounts of dimethyl sulphone, whereas Trajadura wines possessed a high content in 3-(methylthio)propyl acetate and 4-(methylthio)-1butanol. Significant amounts of $N$-3-(methylthiopropyl)acetamide were also found in Trajadura and Pedernã wines in Year 2. Dimethyl sulphone and $N$-3-(methylthiopropyl)acetamide have no important sensory impact. 3-(Methylthio)propyl acetate presents a mushroom, onion and garlic odour; however, its content in wines never exceeds the threshold value, having little influence on wine quality. Significant amounts of 4-(methylthio)-1-butanol were also observed in Azal Branco wines. Concentrations of this compound in wines varied between 9.85 and $28.7 \mu \mathrm{g} / \mathrm{l}$. Values up to $22.4 \mu \mathrm{g} / \mathrm{l}$ were also reported in red wines (Ugliano et al., 2009). This compound has chive, onion, garlic, earthy, metallic-bitter or grassy notes, depending on its concentration in wine, but is not considered a negative influence to wine aroma. Its threshold value was found to be higher than its usual content in wines $(0-180 \mu \mathrm{g} / \mathrm{l})$ (Anocibar Beloqui, 1998; Fedrizzi, Magno, Badocco, et al., 2007; Mestres et al., 2002).

The highest values of 3-(ethylthio)-1-propanol were observed in Alvarinho wines in Year $2(61.0 \mu \mathrm{g} / \mathrm{l})$ and in Avesso wines in Year $1(30.8 \mu \mathrm{g} / \mathrm{l})$. Similar results were reported for other white wines, with concentrations of this compound varying from 6 to $68 \mu \mathrm{g} / \mathrm{l}$ (Baumes et al., 1986; Lavigne, 1996). Significant amounts of 3-methylthiopropionic acid were also found in Alvarinho and Avesso wines. In white wines, 3-methylthiopropionic acid can be detected at concentrations up to $70 \mu \mathrm{g} / \mathrm{l}$; higher contents, up to $1448 \mu \mathrm{g} / \mathrm{l}$, were quantified in cloudy wines (Anocibar Beloqui, 1998; Mestres et al., 2000). Karagiannis and Lanaridis (1999) found 3-methylthiopropionic acid concentrations in white wines varying between 13 and $168 \mu \mathrm{g} / \mathrm{l}$, which were influenced by the yeast strain and the cultivar used. This compound has a perception threshold of $50 \mu \mathrm{g} / 1$ in hydroalcoholic solution and of $244 \mu \mathrm{g} / \mathrm{l}$ in red Merlot wine, and is characterised by rancid/butter, chocolate and roasted odours (Table 1 ).

Avesso wines were also characterised by significant amounts of 2-methyltetrahydrothiophen-3-one and cis- and trans-2-methyltetrahydrothiophen-3-ol. 2-Methyltetrahydrothiophen-3-one contents of wines varied between 42.6 and $245 \mu \mathrm{g} / \mathrm{l}$. Baumes et al. (1986) detected concentrations of 7-45 $\mu \mathrm{g} / \mathrm{l}$ in white wines; however, higher values up to $231 \mu \mathrm{g} / \mathrm{l}$ were reported in Greek white wines and Sauvignon wines, as well as in wines with reduction defects (Chatonnet et al., 1992; Karagiannis \& Lanaridis, 1999; Lavigne, Boidron, \& Dubourdieu, 1992). This sulphur compound possesses a metallic, butane-like odour and a threshold value of $150 \mu \mathrm{g} / \mathrm{l}$ in white wines. Trajadura and Alvarinho wines also contained significant amounts of cis- and trans-2-methyltetrahydrothiophen-3-ol in Year 2. Cis- and trans-2-methyltetrahydrothiophen-3-ol were detected at concentrations of $5-12 \mu \mathrm{g} / \mathrm{l}$ in white wines (Baumes et al., 1986; Rauhut, 1993). Only the trans-isomer has been reported as presenting odour activity, similar to onion and chive-garlic.

Besides the high content in 4-(methylthio)-1-butanol, S-methyl thioacetate, 3-mercapto-1-propanol and in 2-mercaptoethanol, Azal Branco wines are also characterised by low amounts of 2(methylthio)ethanol. Low levels of 2-(methylthio)ethanol were also obtained in Loureiro cultivars. Concentrations of this compound lower than $152 \mu \mathrm{g} / \mathrm{l}$ were reported in white wines (Anocibar Beloqui, 1998; Fedrizzi, Magno, Moser, et al., 2007; Karagiannis \& Lanaridis, 1999; Lavigne, 1996; Ugliano et al., 2009). These concentrations are lower than the threshold values (Table 1 ).

A linear discriminant analysis (LDA) was applied to all wines from both vintages in order to optimise their separation according to grape cultivar. All heavy sulphur compounds concentrations were used and contributed to the analysis. Five LDA factors were effective in discriminating the cultivar employed, explaining $100 \%$ of the total variance. Fig. 2 shows the projection of the wines in a two-dimensional space. Six groups, representing the wines from each cultivar, are clearly observed.

In conclusions, the concentrations of sulphur compounds found in wines were, in general, below their perception threshold values. Experiments show that wines from the six cultivars could be differentiated according to their sulphur compounds content. Low concentrations of sulphur compounds were found in Loureiro, Trajadura and Pedernã wines. However, Loureiro wines showed significant amounts of dimethyl sulphone, whereas Trajadura

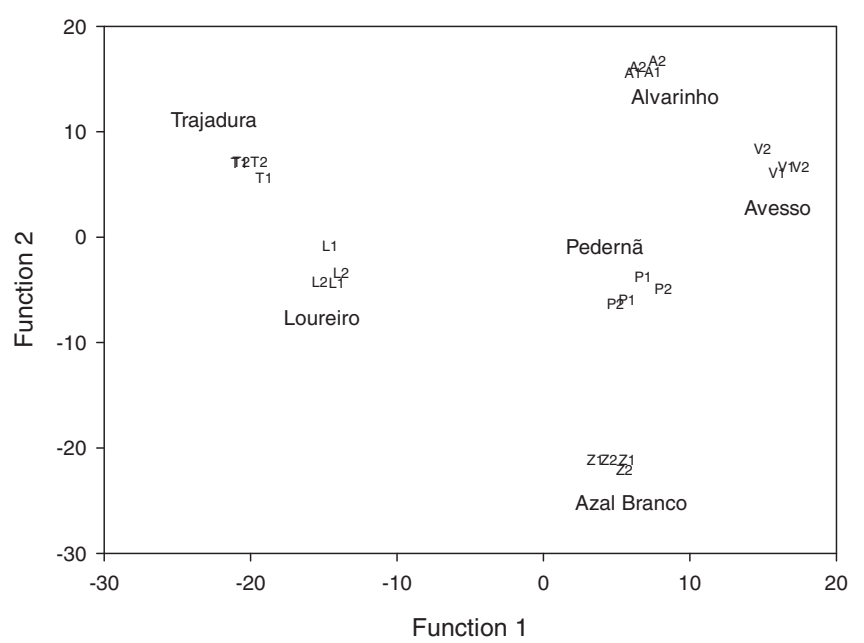

Fig. 2. Linear discriminant analysis: projection of wines from Trajadura (T), Pedernã (P), Alvarinho (A), Loureiro (L), Azal Branco (Z) and Avesso (V), followed by 1 (1st vintage) or 2 (2nd vintage) 
wines presented a high content in 3-(methylthio)propyl acetate and 4-(methylthio)-1-butanol. Alvarinho and Avesso wines showed high concentrations of S-methyl thioacetate, 3-mercapto1-propanol, 3-(ethylthio)-1-propanol and 3-methylthiopropionic acid. Avesso wines also presented significant amounts of 2-methyltetrahydrothiophen-3-one and cis- and trans-2-methyltetrahydrothiophen-3-ol. Azal Branco wines were characterised by low contents in 3-(methylthio)propyl acetate and 2-(methylthio)ethanol, and high contents in S-methyl thioacetate, 3-mercapto-1-propanol and 2-mercaptoethanol. Some differences were also observed according to the year of vintage and may be due to climatic conditions that affect the nutrient levels of grape musts.

It is known that precursors of sulphur compounds are present in grape musts, and may vary with the variety and origin of grapes. Other factors, like climatic conditions, application of fertilizers, vinification procedures and conservation of wines, must be investigated in order to understand their effect on sulphur compounds synthesis. These parameters are known to influence the amino acid metabolism of yeasts which, in turn, is related to the production of some sulphur compounds.

\section{Acknowledgement}

The authors gratefully acknowledge the financial support from FCT (via a Ph.D. fellowship Ref.ㄹ PRAXIS XXI/BD/5062/95).

\section{References}

Anocibar Beloqui, A. (1998). Contribution a létude des composés soufrés volatiles des vins rouges. PhD thesis, University Bordeaux II, Bordeaux, France.

Anocibar Beloqui, A., \& Bertrand, A. (1995). Study of sulfur compounds in wine: Preliminary results. Italian Journal of Food Science, 3, 279-288.

Baumes, R., Cordonnier, R., Nitz, S., \& Drawert, F. (1986). Identification and determination of volatile constituents in wines from different vine cultivars. Journal of the Science of Food and Agriculture, 37, 927-943.

Bouchilloux, P., Darriet, P., Henry, R., Lavigne-Cruège, L., \& Dubourdieu, D. (1998). Identification of volatile and powerful odorous thiols in Bordeaux red wines varieties. Journal of Agricultural and Food Chemistry, 46, 3095-3099.

Chatonnet, P., Dubourdieu, D., \& Boidron, J. N. (1992). Incidence des conditions de fermentation et d'élèvage des vins blancs secs en barriques sur leur constitution en substances cedes par le bois. Science des Aliments, 12, 665-680.

Darriet, P., Lavigne-Cruège, V., \& Tominaga, T. (1999). A paradox: The volatile sulphur compounds responsible for both defects and qualities in wines. In Vigne et Vin Publications International (pp. 127-133), Bordeaux, France.

Dopico-García, M. S., Valentão, P., Guerra, L., Andrade, P. B., \& Seabra, R. M. (2007) Experimental design for extraction and quantification of phenolic compounds and organic acids in white 'Vinho Verde' grapes. Analytica Chimica Acta, 583, $15-22$.

Falqué, E., Fernández, E., \& Dubourdieu, D. (2002). Volatile components of Loureira, Dona Branca, and Treixadura wines. Journal of Agricultural and Food Chemistry, 50, 538-543.

Fedrizzi, B., Magno, F., Badocco, D., Nicolini, G., \& Versini, G. (2007). Aging effects and grape variety dependence on the content of sulphur volatiles in wine. Journal of Agricultural and Food Chemistry, 55, 10880-10887.

Fedrizzi, B., Magno, F., Moser, S., Nicolini, G., \& Versini, G. (2007). Concurrent quantification of light and heavy sulphur volatiles in wine by headspace solidphase microextraction coupled with gas chromatography/mass spectrometry. Rapid Communications in Mass Spectrometry, 21, 707-714.

Ferreira, A., Rodrigues, P., Hogg, T., \& Guedes de Pinho, P. (2003). Influence of some technological parameters on the formation of dimethyl sulfide, 2mercaptoethanol, methionol, and dimethyl sulfone in Port wines. Journal of Agricultural and Food Chemistry, 51(3), 727-732.

Karagiannis, S., \& Lanaridis, P. (1999). The effect of various vinification parameters on the development of several volatile sulfur compounds in Greek white wines of the cultivars Batiki and Muscat of Hamburg. American Journal of Enology and Viticulture, 50(3), 334-342.
Karagiannis, S., \& Lanaridis, P. (2000). Incidence des conditions de conservation des vins blancs sur la teneur en composés soufrés volatils. Vitis, 39(2), 71-78.

Landaud, S., Helinck, S., \& Bonnarme, P. (2008). Formation of volatile sulphur compounds and metabolism of methionine and other sulphur compounds in fermented food. Applied Microbiology and Biotechnology, 77, 1191-1205.

Lavigne, V. (1996). Recherches sur les composés soufrés volatils formés par la levure au cours de la vinification et l'élevage des vins blancs sec. PhD thesis, University of Bordeaux II, Bordeaux, France.

Lavigne, V., Boidron, J. N., \& Dubourdieu, D. (1992). Formation des composés soufrés lourd au cours de la vinification des vins blanc secs. Journal International des Sciences de la Vigne et du Vin, 26(2), 75-85.

Lavigne, V., \& Dubourdieu, D. (1996). Demonstration and interpretation of the yeast lee ability to absorb certain volatile thiols contained in wine. Journal International des Sciences de la Vigne et du Vin, 30(4), 201-206.

Mestres, M., Busto, O., \& Guasch, J. (2000). Analysis of organic sulfur compounds in wine aroma. Journal of Chromatography A, 881, 569-581.

Mestres, M., Busto, O., \& Guasch, J. (2002). Application of headspace solid-phase microextraction to the determination of sulphur compounds with low volatility in wines. Journal of Chromatography A, 945, 211-219.

Moreira, N., Guedes de Pinho, P., \& Vasconcelos, I. (2004). Method for analysis of heavy sulphur compounds using gas chromatography with flame photometric detection. Analytica Chimica Acta, 513, 183-189.

Office International de la Vigne et du Vin. (1990). Recuil des méthodes internationales d'analyse des vins et des moûts. Paris: OIV.

Oliveira, J., Araújo, I., Pereira, O., Maia, J., Amaral, A., \& Maia, M. O. (2004). Characterization and differentiation of five 'Vinhos Verdes' grape varieties on the basis of monoterpenic compounds. Analytica Chimica Acta, 513, 269-275.

Oliveira, J., Faria, M., Sá, F., Barros, F., \& Araújo, I. (2006). C6-alcohols as varietal markers for assessment of wine origin. Analytica Chimica Acta, 563, 300-309.

Park, S., Boulton, R., \& Noble, A. (2000). Formation of hydrogen sulfide and glutathione during fermentation of white grape musts. American Journal of Enology and Viticulture, 51(2), 91-97.

Pripis-Nicolau, L., Revel, G., Bertrand, A., \& Lonvaud-Funel, A. (2004). Methionine catabolism and production of volatile sulphur compounds by Oenococcus oeni. Journal of Applied Microbiology, 96, 1176-1184.

Rapp, A., Güntert, M., \& Almy, J. (1985). Identification and significance of several sulphur-containing compounds in wine. American Journal of Enology and Viticulture, 36(3), 219-221.

Rauhut, D. (1993). Production of sulfur compounds. In G. H. Fleet (Ed.), Wine microbiology and biotechnology (pp. 183-242). Switzerland: Harwood Academic Publishers.

Rauhut, D., \& Kürbel, H. (1995). Identification of wine aroma defects caused by sulphur-containing metabolites of yeasts. In Proceedings of the fifth symposium international d'oenologie: Oenologie 95 (p. 515), Bordeaux, France.

Sarrazin, E., Shinkaruk, S., Tominaga, T., Bennetau, B., Frérot, E., \& Dubourdieu, D. (2007). Odorous impact of volatile thiols on the aroma of young botrytized sweet wines: Identification and quantification of new sulfanyl alcohols. Journal of Agricultural and Food Chemistry, 55, 1437-1444.

Spiropoulos, A., Tanaka, J., Flerianos, I., \& Bisson, L. (2000). Characterisation of hydrogen sulfide formation in commercial and natural wine isolates of Saccharomyces. American Journal of Enology and Viticulture, 51(3), 233-248.

Swiegers, J. H., Bartowsky, E. J., Henschke, P. A., \& Pretorius, I. S. (2005). Yeast and bacterial modulation of wine aroma and flavour. The Australian Journal of Grape and Wine Research, 11, 139-173.

Thomas, C., Boulton, R., Silacci, M., \& Gubler, D. (1993). The effect of elementary sulphur, yeast strain, and fermentation medium on hydrogen sulfide production during fermentation. American Journal of Enology and Viticulture, 44(2), 211-216.

Tominaga, T., \& Dubourdieu, D. (2006). A novel method for quantification of 2methyl-3-furanthiol and 2-furanmethanethiol in wines made from Vitis vinifera grape varieties. Journal of Agricultural and Food Chemistry, 54, 29-33.

Ugliano, M., Fedrizzi, B., Siebert, T., Travis, B., Magno, F., Versini, G., et al. (2009). Effect of nitrogen supplementation and Saccharomyces species on hydrogen sulfide and other volatile sulfur compounds in Shiraz fermentation and wine. Journal of Agricultural and Food Chemistry, 57, 4948-4955.

Vasserot, Y., Steinmetz, V., \& Jeandet, P. (2003). Study of thiol consumption by yeast lees. Antonie van Leeuwenhoek, 83, 201-207.

Vermeulen, C., Gijs, L., \& Collin, S. (2005). Sensorial contribution and formation pathways of thiols in foods: A review. Food Reviews International, 21, 69-138.

Wang, X. D., Bohlscheid, J. C., \& Edwards, C. G. (2003). Fermentative activity and production of volatile compounds by Saccharomyces grown in synthetic grape juice media deficient in assimilable nitrogen and/or pantothenic acid. Journal of Applied Microbiology, 94, 349-359. 